\title{
You Don'T Have To Go Home, BUt You CaN'T EaT HERE: HOW RESTAURANTS DISCRIMINATE AGAINST INDIVIDUALS WITH CELIAC DISEASE UNDER THE AMERICANS WITH DISABILITIES ACT AND WHAT SHOULd Be Done
}

\author{
Michael J. Hooker*
}

I. INTRODUCTION 856

II. A BACKGRound of CELIAC DiseASE AND ARgumENT For

PRoteCTION . 858

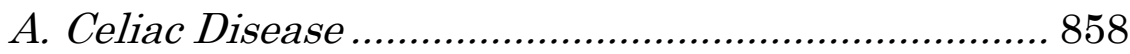

B. The Americans with Disabilities Act ...................... 863

C. Restaurants: The Missing Link................................. 867

D. Putting It All Together......................................... 868

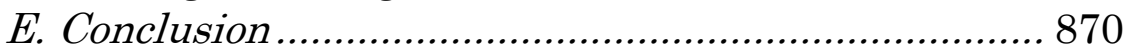

III. The Lesley University Settlement: A PrevieW OF

THINGS TO COME FOR RESTAURANTS.................................. 871

A. The Agreement ................................................... 871

B. Applying this Analysis to Restaurants: Cause for

Concern.... 875

IV. Disproportionate Protection: Why the ADA As APPliEd BY THE DOJ CREATES A DOUble STANDARD BY Protecting Certain Disabilities More Than Others and WHAT SHOULD BE DONE................................................... 879

A. A Truly Protected Disability ................................... 879

B. Lack of Protection for Celiac Sufferers ................... 883

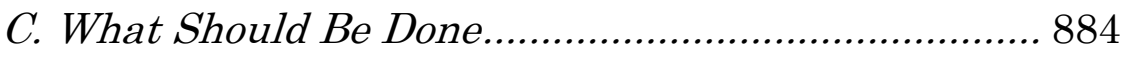

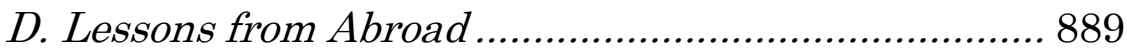

E. Solutions for the Cost of Compliance ...................... 890

F. Crime and Punishment ........................................ 891

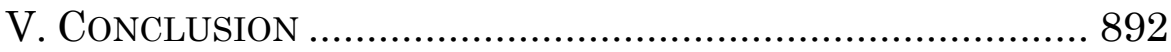

* J.D. Candidate, 215, Indiana University Robert H. McKinney School of Law; B.S., 2011, Butler University College of Business. The author would like to give special recognition to Kathleen M. Kelly, J.D. Along with being his fiancé, she is also a celiac disease sufferer, and the inspiration behind this Note. 


\section{INTRODUCTION}

Imagine an America where restaurants were not accessible for people in wheelchairs. Trying to share a meal with friends or family could lead to the discovery that, not only is there no way to get the wheelchair up to the restaurant without it being carried up the stairs, but there also is not enough room to maneuver it around once inside. The embarrassment and frustration that this could cause nationwide would be appalling. Luckily, the government has taken measures through the Americans with Disabilities Act ("ADA") to prevent this from happening. One product of the $\mathrm{ADA}$ is a long list of specifications providing accessibility standards, such as wheelchair ramp/accessibility mandates as well as walkway width requirements inside of the restaurants, to ensure that physically disabled individuals can equally participate in the restaurant dining experience.

Conversely, there is another group of individuals that are much more discretely excluded from sharing meals with friends and family at many of the nation's restaurants. It is not because they are physically unable to maneuver around the restaurants, but rather that the majority of restaurants in the United States choose not to offer a meal option that is safe for consumption by them without the risk of severe sickness and life-threatening intestinal damage. Discrimination against people who suffer from celiac disease, those who cannot consume products containing wheat, oats, barley, or rye, may not be as openly visible as the previously provided example of discrimination, but it is far more common. Most restaurants that try to offer meals to accommodate this autoimmune disorder fail to actually accommodate those inflicted with it because they include disclaimers on their menus stating the restaurant cannot guarantee the food is safe for consumption by people with the disorder due to potential cross-contamination. This would be similar to a restaurant having a wheelchair ramp with a sign posted at the foot of the ramp stating that the restaurant cannot guarantee the structural integrity of the ramp, so use at your own risk. Consequently, the United 
States Department of Justice ("DOJ") should use the ADA to guarantee the same type of protections to Americans that suffer from celiac disease as are offered to the physically disabled.

There has been a long running debate regarding which mental and physical impairments qualify for protection under the ADA. Many court cases, discussed later, were decided based on a narrow and strict interpretation of what constitutes a disability for purposes of the ADA. Eventually, Congress recognized that the narrow interpretation went against the overall policy rationale of the $\mathrm{ADA}$ and amended the law in order to limit courts' discretion in interpreting which disabilities should receive protection. The ADA Amendments Act of 2008 vastly broadened the scope of impairments that are to be protected under the ADA by including things such as eating as a "major life activity" and providing that anyone who is "substantially limited" in doing so should be considered to be "disabled" for purposes of the law. The awareness and diagnosis of celiac disease, an autoimmune condition has also grown tremendously in recent years. Because of the symptoms of the disease and the ADA Amendments Act of 2008 , its "protected status" under the ADA has become an unavoidable issue.

For Americans, eating out has arguably overtaken baseball as the national pastime. However, acknowledging celiac disease as a disability could create many potential obstacles for restaurants trying to cash in on Americans' eating habits. Recently a settlement was reached between Lesley University and the United States based on an alleged ADA violation because the University was not providing gluten free options for sufferers of celiac disease that attended the school. ${ }^{1}$ The question of how this settlement will impact the obligations of the restaurant industry to provide gluten free options remains. The impact could potentially be that places of public accommodation that serve food, such as restaurants, will be required to

1 Settlement Agreement, United States v. Lesley Univ., DJ 202-36-

231 (Dec. 20, 2012), available at http://www.ada.gov/ lesley_university_sa.htm [hereinafter Settlement]. 
provide a certified gluten free menu in order to avoid discriminatory practices as classified by the ADA.

The remainder of this Note discusses the new found necessity to offer the protections of the ADA to individuals with celiac disease, specifically in the context of dining at restaurants. To increase the reader's understanding of how these things are interrelated, Part II sets forth a background of celiac disease as well as a background of the ADA along with how it applies to restaurants. Part III provides an analysis of a recent settlement agreement reached between the DOJ and Lesley University that illustrates one of the first suggestions by the DOJ that celiac disease is a protected disability under the ADA. The implications of the terms of the settlement agreement for the restaurant industry are also discussed in Part III of this Note. A comparison between the modifications that restaurants are mandated to make by the ADA for the physically disabled requiring the use of mobility devices and the modifications currently mandated for individuals with celiac disease is drawn in Part IV to show the disparity in the standards. Part IV then explains what should be required of restaurants in order to avoid discriminating against sufferers of celiac disease including following the lead of innovative restaurants as well as government programs in other countries.

\section{A BACKGRound OF CELIAC DiSEASE AND ARGUMENT FOR PROTECTION}

\section{A. Celiac Disease}

Celiac disease, also known as celiac sprue, non-tropical sprue, and gluten-sensitive enteropathy, is an inherited genetic disease. ${ }^{2}$ Sufferers of celiac disease cannot tolerate the protein gluten, which is found in wheat, oats, barley, and rye. ${ }^{3}$ Ingesting even trace amounts of gluten triggers

2 Celiac Disease, Nat'l Inst. Of Diabetes \& Digestive \& Kidney DISEASES, http://digestive.niddk.nih.gov/ddiseases/pubs/celiac/ (last visited Mar. 22, 2015) [hereinafter Nat'l Digestive Diseases].

3 Id. 
an autoimmune reaction in which the body produces antibodies that attack and destroy the villi in the small intestine causing a wide array of gastrointestinal symptoms. ${ }^{4}$ Villi are the "tiny, fingerlike protrusions lining the small intestine" that absorb the nutrients from food into the bloodstream, and without them, a person will become malnourished regardless of the amount of food he or she eats. ${ }^{5}$ Because of this, it is easy to see the life threatening consequences that exposure to any amount of gluten can have for an individual with the disease.

Blood testing, genetic testing, and biopsies of the small intestine are all common ways of diagnosing celiac disease. ${ }^{6}$ Symptoms can vary widely from person to person. ${ }^{7}$ Among children, it is more likely that the symptoms will manifest in the form of digestive issues such as diarrhea, abdominal pain/bloating, and vomiting. 8 However, adults can show a wide variety of symptoms ranging from joint pain to iron deficiency to depression and even seizures, none of which would lead someone to think the food he or she had been consuming was the root of the problem. ${ }^{9}$ The disease can be life threating and cause problems such as increased risk of certain types of cancer, osteoporosis, nervous system disease, pancreatic disease, and various organ disorders. ${ }^{10}$ The importance of getting tested cannot be overstated due not only to the intestinal damage that can be caused, but also because of the elevated risks of other diseases that

4 Center for Celiac Research \& Treatment: Gluten Sensitivity FAQ, MASSGENERAL HosP., http://www.massgeneral.org/children/ services/celiac-disease/gluten-sensitivity-faq.aspx (last visited Mar. 22, 2015) [hereinafter Gluten Sensitivity FAQ].

5 Nat'l Digestive Diseases, supra note 2.

6 Gluten Free Diet Fad: Are Celiac Disease Rates Actually Rising?, CBSNEWS (July 31, 2012, 5:13 PM), http://www.cbsnews.com/news/gluten free-diet-fad-are-celiac-diseaserates-actually-rising/.

7 Nat'l Digestive Diseases, supra note 2.

8 Id.

$9 \mathrm{Id}$.

10 Center for Celiac Research \& Treatment: Celiac Disease FAQ, MASSGENERAL HOSP., http://www.massgeneral.org/children/services/ celiac-disease/celiac-disease-faq.aspx (last visited June 16, 2015) [hereinafter Celiac Disease FAQ]. 
have been linked to celiac disease as well as the multitude of symptoms through which the disease can manifest.

As previously mentioned, celiac disease is an inherited genetic disorder, but it can either be active in an individual at birth or lay dormant and be triggered by a later life event that is a stressor to the body. ${ }^{11}$ There have been some gene mutations identified that apparently increase the risk of potentially developing the disease, but just having one of these genetic mutations does not guarantee that a person will develop celiac disease. ${ }^{12}$ For these people who are genetically predisposed to celiac disease, it can become active after the body experiences one a stressful life event, as mentioned above, such as surgery, childbirth, pregnancy, viral infection, or even severe emotional distress. ${ }^{13}$

Celiac disease "may be one of the most common genetic diseases" as it affects an average of 1 in 133 average Americans. ${ }^{14}$ One in thirty-nine people that have an aunt, uncle, or cousin (second-degree relative) with celiac disease also have it themselves. ${ }^{15}$ Americans with a first-degree relative who suffers from the disease have a one in twentytwo chance of also having it themselves. ${ }^{16}$ These numbers show that as people in genetically predisposed families continue to reproduce, it is only logical that the number of people with celiac disease will continue to grow in the United States and issues associated with it will become more and more unavoidable.

Another common term heard when discussing celiac disease is gluten sensitivity. Many people use the term

\footnotetext{
11 Nat'l Digestive Diseases, supra note 2.

12 Celiac Disease, MAYO CLINIC (May 22, 2013), http://www.mayoclinic.org/diseases-conditions/celiacdisease/basics/causes/con-20030410.

13 Id.

14 Laura E. Derr, When Food Is Poison: The History, Consequences, and Limitations of the Food Allergen Labeling and Consumer Protection Act of 2004, 61 FoOD \& DRUG L.J. 65 (2006).

15 Celiac Disease Facts and Figures, Univ. Chi. Celiac Disease CENTER, http://www.uchospitals.edu/pdf/uch_007937.pdf (last visited Mar. 22, 2015).

16 Id.
} 
interchangeably, but there is a distinct difference between people with celiac disease and those who are gluten sensitive. Gluten sensitivity is a term used to describe people that react similarly to those with celiac disease after ingesting gluten, but do not experience the same intestinal damage caused by the production of attacking antibodies that celiac sufferers do. ${ }^{17}$ It differs from celiac disease because the response of the immune system is innate, meaning that although the response is immediate, it has no "immunological memory" and will not cause an attack on the body's own tissue like celiac disease does. ${ }^{18}$ Essentially, people with gluten sensitivity have the same symptoms but without the long-term intestinal damage or the same elevated risks of many other diseases such as cancer and the other various organ diseases suffered by people with celiac disease that are listed above. ${ }^{19}$ Therefore, for the estimated eighteen million Americans that experience nonceliac gluten sensitivity, it "has been clinically recognized as less severe than celiac disease." 20

Food allergies are also a common topic of conversation in the realm of celiac disease and gluten sensitivity. Food allergies are the result of the immune system deciding that a certain food is dangerous to the body, which can cause many of the same symptoms as celiac disease. ${ }^{21}$ The reaction initiated by the immune system is typically shortlived and does not cause permanent harm to the body once reversed. ${ }^{22}$ The exceptions to this generality are those allergies that cause anaphylaxis and can lead to death if not properly treated. ${ }^{23}$ However, these reactions can be

17 What IS Non-Celiac Gluten Sensitivity?, NAT'L Found. For CELIAC AWARENESS, http://www.celiaccentral.org/non-celiac-glutensensitivity/introduction-and-definitions/ (last updated Mar. 22, 2015).

18 Id.

19 Id.

$20 \mathrm{Id}$.

21 Allergies and Intolerance, Univ. Chi. Celiac Disease Center, http://www.cureceliacdisease.org/wpcontent/uploads/2011/09/CDCFactSheets9_Allergies.pdf （last visited Mar. 22, 2015).

22 Id.

23 Id. 
controlled through the use of a medication known epinephrine. ${ }^{24}$ Therefore, even though the initial reaction may be as severe as that of a celiac disease sufferer, the symptoms are typically immediately reversible.

There is currently no cure for celiac disease, nor is there a way to control the body's reaction. ${ }^{25}$ Thus far, the only treatment that has been discovered for the disease is a strict adherence to a gluten free diet. ${ }^{26}$ If this is done, the damage to the small intestine caused by gluten can be maintained and possibly reversed to some extent. ${ }^{27}$ However, consuming any amount of gluten, even trace amounts that may not cause an attack evidenced by physical symptoms, can cause an elevation in levels of antibodies signifying intestinal damage, and it may takes weeks for those levels to return to normal. ${ }^{28}$ Therefore, it is extremely important for the health and well-being of celiac sufferers to be absolutely sure that everything they eat, drink, or otherwise consume is $100 \%$ gluten free. ${ }^{29}$ For many, this is a daunting challenge that presents many difficulties when eating out or travelling due to the lack of certified gluten free options in restaurants as well as a lack of restaurant staff training on how to handle and prepare food for individuals with the disease. ${ }^{30}$ The University of Chicago Celiac Disease Center is currently striving to remedy this problem by discovering a cure for the disease and hopes to do so by the year 2026, but as of now, the gluten free diet remains the only identified treatment. ${ }^{31}$

24 Facts and Statistics, FoOD Allergy Res. \& EDUC., http://www.foodallergy.org/facts-and-stats (last visited Mar. 22, 2015).

25 What I Need to Know About Celiac Disease, NAT'L Inst. OF Diabetes \& Digestive \& KidneY Diseases, http://digestive.niddk.nih.gov/ddiseases/pubs/celiac_ez/ (last updated Sept. 11, 2013).

26 Id.

27 Id.

28 Start on a Gluten-Free Diet, Univ. Chi. Celiac Disease Center, http://www.cureceliacdisease.org/living-with-celiac/guide/treatment (last visited Mar. 22, 2015).

29 Id.

$30 I d$.

31 Id. 
Even though many foods are naturally gluten free, there are still many dangers associated with those foods for celiac disease sufferers. ${ }^{32}$ Cross-contamination is often thought of in the sense of preventing the transfer of harmful bacteria from one object to another like bacteria from raw chicken to fresh vegetables that can cause food poisoning, ${ }^{33}$ but it can also be used to describe the transfer of allergens from one object to another. ${ }^{34}$ Cross-contamination can occur in the manufacturing process, in the food preparation process, and/or while the food is being cooked. ${ }^{35}$ If the food is processed in the same area as allergen-containing products, prepared with utensils that have not been properly cleaned since coming in contact with allergens, cooked on the same surface as food containing allergens, or even exposed to dust from nearby allergenic foods, it can be cross-contaminated and cause allergic reactions for consumers with celiac disease. ${ }^{36}$ Restaurants are a place where many celiac disease sufferers are at high risk of having their gluten free food cross-contaminated because there are an abundance of opportunities for cross-contamination to occur as well as a lack of employee training about how to safely serve those suffering from food allergies. ${ }^{37}$ For example, a restaurant that serves pizza and uses regular wheat flour when stretching and tossing the dough can contaminate every other surface in the kitchen due to the transfer of gluten via the particles of flour that get tossed into the air along with the dough.

\section{B. The Americans with Disabilities Act}

In 1990, Congress enacted the Americans with Disabilities Act to "provide a clear and comprehensive

32 Derr, supra note 14.

33 Prevent Cross-Contamination, Minn. DeP'T of Health, http://www.health.state.mn.us/foodsafety/clean/xcontamination.html (last visited Mar. 22, 2015).

34 Derr, supra note 14 , at 85.

35 Id.

36 Id.

37 Id. at 92 . 
national mandate for the elimination of discrimination against individuals with disabilities." 38 A disability is defined as "(A) a physical or mental impairment that substantially limits one or more of the major life activities of such individual; (B) a record of such an impairment; or (C) being regarded as having such an impairment." 39 This enactment was based on the finding that "historically, society has tended to isolate and segregate individuals with disabilities" and that this "continue[s] to be a . . pervasive social problem" while "discrimination against individuals with disabilities persists in such critical areas as. . public accommodations ...." 40

Congress originally intended a very a broad scope of protection to be offered for individuals under the ADA. ${ }^{41}$ However, in the later part of the 1990s and early 2000s, the Supreme Court interpreted the definition of disability very narrowly and excluded many individuals that Congress had initially intended to protect. 42

In Sutton V. United Airlines, the Supreme Court significantly narrowed the definition of a disability. 43 In Sutton, twin sisters each had severe myopia, (uncorrected vision of 20/200 or worse) "but with the use of corrective lens, each has vision that is $20 / 20$ or better." 44 The sisters applied to be airline pilots, but were denied the opportunity because they did not meet the airline company's minimum uncorrected vision requirement of 20/100. ${ }^{45}$ As a result, the women filed a charge of disability discrimination under the ADA. ${ }^{46}$ The Court decided the women were not actually

\footnotetext{
3842 U.S.C. $\S 12101(\mathrm{~b})(1)$ (2015).

39 Id. $\S 12102(1)$.

$40 \quad I d . \S 12101(\mathrm{a})(2)-(3)$.

41 ADA Amendments Act of 2008, Pub. L. No. 110-325, 122 Stat. 3553 (2008).

42 Id.

43 Sutton v. United Airlines, Inc., 527 U.S. 471 (1999), superseded by statute as stated in, Rohr v. Salt River Project Agric. Imp. \& Power Dist., 555 F.3d 850, 853 (9th Cir. 2009).

44 Id. at 475.

45 Id. at 476.

46 Id.
} 
disabled in the context of the ADA based on the reasoning that a disability only substantially limits a major life activity if the physical or mental impairment cannot be corrected by medication or other measures. ${ }^{47}$ Therefore, because the women had glasses that corrected their severe myopia, they were not protected by the ADA.

In Toyota Motor Manufacturing, Kentucky, Inc. $v$. Williams, an employee of an automobile manufacturer was diagnosed with bilateral tendinitis, among other various nerve and tendon conditions, after performing functions of her job. ${ }^{48}$ The woman's conditions eventually progressed to the point that her doctor placed her on a "no-work-of-any" kind restriction." 49 She was subsequently terminated by her employer on the basis of poor attendance, which led her to file a disability discrimination suit under the ADA because her conditions caused her to be substantially limited in the major life activities of performing "manual tasks" and "working" among other things. ${ }^{50}$ In analyzing the application of the ADA to this case, the Supreme Court further restricted the definition of disability by saying that the terms "substantially" and "major" "need to be interpreted strictly to create a demanding standard for qualifying as disabled ...." 51

Congress recognized that the Supreme Court's interpretation of the term disability set the standard for obtaining protection under the ADA at a level that was much more strict than originally intended. 52 In response, Congress enacted the ADA Amendments Act of 2008 in order to reinstate "a broad scope of protection to be available under the ADA" and to reject the Supreme Court's limitation of the definition of disability as stated in theses

47 Id. at $482-83$.

48 Toyota Motor Mfg., Ky., Inc., v. Williams, 534 U.S. 184, 187 (2002), superseded by statute as stated in, Rohr v. Salt River Project Agric. Imp. \& Power Dist., 555 F.3d 850, 853 (9th Cir. 2009).

49 Id. at 190.

$50 \mathrm{Id}$.

51 Id. at 197.

52 ADA Amendments Act of 2008, Pub. L. No. 110-325, 122 Stat. 3553 (2008). 
specific cases. ${ }^{53}$ Congress kept the original definition of disability in the amended text, ${ }^{54}$ but added a nonexhaustive list of major life activities to be protected by the ADA including but "not limited to, caring for oneself, performing manual tasks, seeing, hearing, eating, sleeping, walking, standing, lifting, bending, speaking, breathing, learning, reading, concentrating, thinking, communicating, and working." 55

A person is considered substantially limited in the performance of a major life activity if the "individual is unable to perform a basic function that the average person in the general population can perform ...." 56 A person can also be considered substantially limited if he or she "is significantly restricted in the condition, manner, or duration under which [the individual] can perform a particular major life activity as compared to an average person in the general population." 57 The amendments to the ADA also specifically provided that the term "substantially limits" should be interpreted consistently with the ADA's purpose to provide broad coverage. 58 Presumably in direct response to Sutton, the ADA now states, "The determination of whether an impairment substantially limits a major life activity shall be made without regard to the ameliorative effects of

mitigating measures such as (I) medication ... (II) use of assistive technology; (III) reasonable accommodations . . . or (IV) learned behavioral. . .modifications." 59 Therefore, the threshold for substantially limits appears relatively easy to meet, and a person may be considered "substantially limited" in a major life activity even if the individual has taken measures to mitigate the effects of the disability.

53 Id.

5442 U.S.C. $§ 12102$ (2015).

$55 \mathrm{Id}$.

56 Land v. Baptist Med. Center, 164 F.3d 423, 424 (8th Cir. 1999).

57 Id. at $424-25$.

5842 U.S.C. $\S 12102(4)(B)(2015)$.

59 Id. $\S 12102(4)(\mathrm{E})(\mathrm{i})(\mathrm{I})-(\mathrm{IV})$. 


\section{Restaurants: The Missing Link}

The three major subchapters of the ADA address discrimination in regards to employment, public services, and public accommodations and services operated by private entities respectively. 60 Under the ADA, a "restaurant, bar, or other establishment serving food or drink" is considered to be a place of public accommodation as long as the operations of the public accommodation affect commerce. ${ }^{61}$ It is extremely difficult for a restaurant to avoid the $\mathrm{ADA}$ on the basis that it does not affect commerce because Congress has the right to regulate interstate and intrastate activities that affect commerce regardless of the entity's individual impact on interstate commerce, "so long as the entity engages in a class of activities that affects interstate commerce." ${ }^{62}$ The Supreme Court's previous recognition that "the restaurant industry unquestionably affects interstate commerce in a substantial way" 63 as cited in Pinnock v. International House of Pancakes Franchisee solidifies all restaurants' classification as a place of public accommodation under the ADA.

The types of discrimination prohibited by the ADA for places of public accommodation are denial of participation, participation in an unequal benefit, and providing a separate benefit to the disabled class. ${ }^{64}$ One way for places of public accommodation to avoid discriminating against the disabled is to "make reasonable modifications in policies, practices, or procedures, when such modifications are necessary to afford such goods, services, facilities, privileges, advantages, or accommodations to individuals with disabilities . . ." 65 The place of public accommodation can avoid having to make a reasonable accommodation if

60 Americans with Disabilities Act of 1990, 42 U.S.C. $\S \S 12101^{-}$ 12213 (amended 2008).

61 Id. $\S 12181(7)(\mathrm{B})$.

62 Pinnock v. Int'l House of Pancakes Franchisee, 844 F. Supp. 574, 578 (S.D. Cal. 1993).

63 Id. at 579 (quoting Katzenbach v. McClung, 379 U.S. 294, 303-04 (1964)).

6442 U.S.C. $\S 12182(\mathrm{~b})(1)(\mathrm{A})(2015)$.

65 Id. $§ 12182(\mathrm{~b})(2)(\mathrm{A})(\mathrm{ii})$. 
"the entity can demonstrate that making such modifications would fundamentally alter the nature of such goods, services, facilities, privileges, advantages, or accommodations." 66

Based on the finding that a restaurant is a place of public accommodation, none of the previously mentioned forms of discrimination can be present in regards to a disabled class. If celiac disease sufferers are recognized as a disabled class, not providing gluten free options would be considered denial of participation and the restaurant would be guilty of discrimination. Furthermore, only offering one or two gluten free options on an otherwise expansive menu could also be seen as discrimination by allowing participation but in an unequal benefit. Therefore, if celiac disease is classified as a disability under the new, more encompassing standards, it is likely that restaurants will be found to discriminate against them and will be forced to make reasonable accommodations to remedy the discrimination.

\section{Putting It All Together}

The determination that individuals with celiac disease are statutorily disabled is a relatively easy conclusion to draw. Celiac disease is an autoimmune disease that prevents individuals from being able to eat wheat, oats, barley, or rye. ${ }^{67}$ Ingesting even trace amounts of these foods can lead to serious, life threatening complications involving the digestive and bowel systems and can also have serious repercussions on an individual's ability to reproduce. ${ }^{68}$ The broadening of the definition of disability resulting from the ADA Amendments Act of 2008 includes eating as a major life activity. ${ }^{69}$ Major life activities also include the operation of the major bodily functions of the digestive, bowel, and reproductive functions. ${ }^{70}$ Therefore,

\footnotetext{
66 Id.

67 Nat'l Digestive Diseases, supra note 2.

68 Id.

6942 U.S.C. $\S 12102(2)(\mathrm{A})(2015)$.

70 Id. $\S 12102(2)(\mathrm{B})$.
} 
the complications created by celiac disease affect at least one major life function covered by the ADA.

The standard for what is considered substantially limited has also been reinterpreted to provide for broad coverage of individuals under the ADA. ${ }^{71}$

The amended ADA defines many terms but does not define substantially limited. 72 However, one of the enumerated purposes of the ADA Amendments Act was to reject the demanding strict interpretation requirement of the term "substantially limits" that Toyota Motor Manufacturing, Kentucky, Inc. $v$. Williams imposed. 73 Congress provided guidance for how to interpret substantial limits by including the statement, "The term . . . shall be interpreted consistently with the findings and purposes of the ADA Amendments Act of 2008."74 The purpose of the ADA Amendments, to promote broad coverage to individuals, further supports the conclusion that individuals with celiac disease should be considered substantially limited in the major life activities of eating and operation of major bodily functions due to their inability to consume wheat, oats, barley, rye, or their byproducts.

Moreover, celiac sufferers cannot be excluded from the classification of substantially limited because the condition can be controlled with a gluten free diet. As previously mentioned, the ADA Amendments Act of 2008 specifically provided that an individual who would be considered substantially limited cannot be excluded from that status just because the disease can be controlled through mitigating measures. ${ }^{75}$

Therefore, celiac disease should be defined as a disability under the ADA because it is a physical impairment that substantially limits one or more major life activities of an individual. In a recent settlement agreement (discussed

71 Id. $§ 12102(4)(\mathrm{E})(\mathrm{i})$.

72 See id.

73 ADA Amendments Act of 2008, Pub. L. No. 110-325, 122 Stat. 3553 (2008).

7442 U.S.C $\S 12102(4)(B)(2015)$.

75 Id. $\S 12102(4)(\mathrm{E})(\mathrm{i})$. 
below), the DOJ also reached this conclusion. ${ }^{76}$ Some who opposed the ADA Amendments Act of 2008 because of its inclusiveness agree that celiac disease is considered a disability under the enhanced definition. ${ }^{77}$

On the other hand, people with gluten sensitivity, as well as most food allergies, would most likely not be considered disabled for the purposes of the ADA. For the most part, these individuals do not experience the permanent damage to their body tissue that is caused by autoimmune disorders like celiac disease. The DOJ has indicated that only those experiencing an autoimmune response to food would be considered substantially limited in the major life activity of eating with the possible inclusion of individuals at risk of anaphylaxis. ${ }^{78}$

\section{E. Conclusion}

So far, an analysis of the ADA, ADA Amendments Act of 2008 , and case law has shown that a restaurant is a place of public accommodation, and therefore, governed by the ADA. Further evaluation of the statutes and the legislative intent along with an in depth exploration of celiac disease has also provided the logical inference that celiac disease is, in fact, a disability warranting protection by the ADA. This leaves the extremely difficult question of what restaurants should be required to do in order to provide reasonable accommodations to celiac disease sufferers to avoid discrimination claims under the ADA. The following settlement agreement closely parallels this very issue and sheds light on all of the potential modifications faced by restaurants if this becomes widely recognized.

76 Questions and Answers About the Lesley University Agreement and Potential Implications for Individuals with Food Allergies, U.S. DEP'T OF JUST. (Jan. 2013), http://www.ada.gov/ q\&a_lesley_university.htm [hereinafter Questions and Answers].

77 Paul R. Klein, The ADA Amendments Act of 2008: The Pendulum Swings Back, 60 CASE W. RES. L. REV. 467, 485 (2010).

78 Questions and Answers, supra note 76. 


\title{
III. The LeSLEy UnIVERSITY SeTTLEMENT: A PREVIEW OF THINGS TO COME FOR RESTAURANTS
}

\begin{abstract}
A. The Agreement
Lesley University has approximately 8,000 students and is a private nonprofit university in Cambridge, Massachusetts. 79 Lesley University, as many universities do, had a policy that required all students living on campus to participate in and pay for its meal plan. ${ }^{80}$ The meal plan provided no guarantee that students with celiac disease could eat any of the available options without risk of that food being contaminated. ${ }^{81}$ In October 2009, a complaint was filed with the DOJ against Lesley University for alleged violations of Title III of the ADA. ${ }^{82}$ This alleged violation of the ADA stemmed from the University's failure "to make necessary reasonable, modifications in policies, practices, and procedures to permit students with celiac disease. . . to fully and equally enjoy the privileges, advantages, and accommodations of its food service and meal plan system." 83

Under the ADA, any "nursery, elementary, secondary, undergraduate, or postgraduate private school, or other place of education" is considered a place of public accommodation. ${ }^{84}$ Lesley University did not dispute that it met the requirements of a public accommodation under the aforementioned entity classification. ${ }^{85}$ This section of the ADA prohibits "a private university from discriminating against any individual on the basis of disability in the full and equal enjoyment of the university's goods, services, facilities, privileges, advantages, or accommodations." 86
\end{abstract}

\footnotetext{
79 Settlement, supra note 1.

80 Questions and Answers, supra note 76.

81 Id.

82 Settlement, supra note 1.

$83 \mathrm{Id}$.

8442 U.S.C. § 12181(7)(J) (2015).

85 Settlement, supra note 1.

86 Id. (citing 42 U.S.C. $\S 12182$ (2015); 28 C.F.R. $\S \S 36.201,36.202)$.
} 
The Settlement Agreement (the "Agreement") between the DOJ and the University does not explicitly state that celiac disease is a disability under the ADA. ${ }^{87}$

The Agreement simply states, "[f]ood allergies may constitute a disability under the ADA . . . ." 88 The Agreement then continues to give the example of celiac disease as an autoimmune disorder that affects the major life activity of eating as well as various bodily functions, but never explicitly states that celiac disease is protected under the ADA. ${ }^{89}$ The DOJ, however, released a Questions and Answers report regarding the settlement agreement which concluded that individuals with "autoimmune responses to certain foods" would be included under the definition of disability as it pertains to the ADA thereby clearly recognizing the protected status of celiac disease under the ADA. ${ }^{90}$

Lesley University recognized that as a public accommodation it must make the "reasonable modifications" to its meal plan policies that "are necessary to afford goods, services, facilities, privileges, advantages, or accommodations to individuals with disabilities." 91 After the University acknowledged that it was a public accommodation and the DOJ recognized celiac disease as a disability under the ADA, "[t]he Parties agree[d] that it is in the Parties' best interests . . . to resolve this dispute amicably and without litigation." ${ }^{2}$ The Agreement also very explicitly laid out that the Agreement was "voluntarily entered into" and that no part of the agreement should be interpreted as Lesley University admitting to violating the ADA. 93 However, it seems highly unlikely that the University would go out of its way to implement the numerous changes to its food services and bear the

\footnotetext{
87 See id.

88 Id.

89 Id.

90 Questions and Answers, supra note 76.

91 Settlement, supra note 1.

92 Id.

93 Id.
} 
associated cost burdens, discussed below, if it did not believe it was in violation of the ADA.

To be in compliance with the ADA, a public accommodation, such as Lesley University, only has to make "reasonable modifications" to its services for those with disabilities if "making such modifications would [not] fundamentally alter the nature of the goods, services, facilities, privileges, advantages, or accommodations" of the entity. 94 The Agreement specifically identifies twelve "Resolution Terms" that the University and the DOJ agreed upon in order to bring the University's food services into full compliance with the ADA. ${ }^{95}$ Therefore, it follows that all of the agreed upon "Resolution Terms" were considered "reasonable modifications" to Lesley University's food services.

Some terms of the Agreement require simple procedural changes while others require substantial change to the University's food services policies. ${ }^{96}$ The first term of the Agreement requires Lesley University to formally recognize its status as a public accommodation under Title III of the ADA and accept the accompanying obligations. ${ }^{97}$ Other terms, however, were much more extensive.

Substantial modifications were mandated for the University's dining services. ${ }^{98}$ Notices must be posted to inform individuals of all of the potential allergens used in the food preparation area and letting the students know to inform a server of any accommodation needed.99 Lesley University agreed to provide allergen free meals to those individuals requiring a modified meal plan due to allergies that are nutritionally comparable to offerings on the normal meal plan while taking precautionary steps to avoid crosscontamination. 100 The University will now provide a preorder option to students with celiac disease that allows
94 Id.
95 Id.
96 Id.
97 Id.
98 Id.
99 Id.
100 Id. 
them request their meals as long as they do so 24 hours in advance so the proper ingredients can be obtained. 101 All of the meals pre-ordered will be prepared in a dedicated allergen free area of the kitchen of the main dining hall and stored accordingly. ${ }^{102}$ In order to provide the meals in the most integrated setting possible, pre-ordered meals can be delivered to any Lesley University dining hall requested. 103 A separate food preparation and storage room containing a refrigerator, freezer, sink, counter area, cabinets, and separate appliances including a microwave and toaster also has to be made available to individuals with celiac disease through key card access. ${ }^{104}$ Individuals with celiac disease must also be allowed to submit "shopping lists" of requested food that the Food Service Provider must stock in the food preparation room at least once per week. ${ }^{105}$

Following suit of the modifications to the dining services, the Agreement also mandated educational programs for the kitchen staff. 106 Food Service Managers are now required to be trained on how to comply with the terms of the Agreement, complete a "ServSafe" food handling and food service management course, and meet with a nutritionist annually to discuss the nutritional needs of students with celiac disease. 107 The Food Service Staff of Lesley University must be trained on terms of the Agreement, must complete training twice per year provided by the Food Service Provider including instruction on celiac disease and how to handle questions regarding it, and also must hold monthly meetings to address allergy awareness. ${ }^{108}$

Possibly the most concerning term of the settlement for places of public accommodation that serve food such as restaurants is that Lesley University agreed to pay fifty thousand dollars to the individual that originally filed the complaint with the DOJ in exchange for the individual

$\begin{array}{ll}101 & I d . \\ 102 & I d . \\ 103 & I d . \\ 104 & I d . \\ 105 & I d . \\ 106 & I d . \\ 107 & I d \\ 108 & I d .\end{array}$


signing a Waiver and Release of Claims. ${ }^{109}$ This evidences the potential monetary liability that restaurants could be subjected to as a result of the newly protected status of celiac disease. Based on the scope of the terms of the Agreement regarding modifications to existing policies, the threshold for what is considered to be a reasonable accommodation is very high.

\section{B. Applying this Analysis to Restaurants: Cause for Concern}

The 2013 settlement between the DOJ and Lesley University left many wondering about the implications that mandating a food service provider to provide gluten free options would have on the restaurant industry. ${ }^{110}$ After all, restaurants are a public accommodation just the same as Lesley University, which was mandated to provide gluten free options. ${ }^{111}$ However, a report released by the DOJ following the Lesley University Settlement Agreement posed the question, "Does the ADA require that all public accommodations that serve food, like restaurants, also serve gluten free or allergen-free food?" 112 The answer, quite simply, was "No." 113 The DOJ differentiated Lesley University's meal plan from restaurants on the basis that the meal plan was mandatory which required the University to provide "reasonable modifications" to avoid discriminating against students with celiac disease. 114 It further stated the obligations for restaurants that serve the public are different. ${ }^{115}$ However, the DOJ does not elaborate on what the obligation of a restaurant is. Furthermore, the ADA itself does not distinguish between

\footnotetext{
109 Id.

110 Mary Clare Jalonick, Food Service Vulnerable to Food Allergy Lawsuits, USA TODAY, (Jan. 18, 2013, 1:10 PM), http://www.usatoday.com/story/news/nation/2013/01/18/food-serviceallergy-lawsuits/1845335/.

11142 U.S.C. § 12181(7)(B) (2015).

112 Questions and Answers, supra note 76.

113 Id.

114 Id.

115 Id.
} 
mandatory and voluntary services offered by places of public accommodation for the purposes of discrimination. Therefore, the distinction made by the DOJ is not supported by the ADA, and whether a service is mandatory or voluntary should have no impact on whether or not a place of public accommodation can engage in discrimination.

Because of the severity of the side effects of ingesting gluten, celiac disease sufferers have to be extremely cautious when choosing a restaurant to dine at. ${ }^{116}$ In recent years, many restaurants have developed gluten free menus in order to capitalize on the market of the increasing popularity of participating in a gluten free diet. Chili's offers a standard example of the gluten free policy at many restaurants. The restaurant offers a gluten free menu containing a full page of "Suggested Menu Options for Wheat/Gluten Allergies" containing everything from salads to steaks, chicken, and burgers. ${ }^{117}$ The extensive menu appears accommodating to celiac disease sufferers, but it includes a disclaimer rendering itself unsafe. ${ }^{118}$ The disclaimer states:

The following menu options are based on current ingredient information from our suppliers and their stated absence of what and gluten-containing ingredients within these items. Please be aware that during normal operations involving shared cooking and preparation areas, including common fryer oil, the possibility exists for food items to come in contact with wheat and gluten-containing ingredients. Due to these circumstances, we are unable to guarantee that any menu items

\footnotetext{
116 Nat'l Digestive Diseases, supra note 2.

117 Allergen Menu, Menu Items Made Without Wheat and GlutenContaining Ingredients, CHILIS.COM, http://www.chilis.com/EN/ LocationSpecificPDF/MenuPDF/001.005.0000/Chilis\%20Allergen\%20Ge neric.pdf?AspxAutoDetectCookieSupport=1 (last visited Mar. 22, 2015). 118 Id.
} 
can be completely free of allergens or meet Gluten-Free labeling standards. ${ }^{119}$

Because of this disclaimer, it is extremely dangerous for celiac sufferers to eat at Chili's. Disclaimers very similar to this accompany gluten free menus at countless other places such as Olive Garden and Applebee's. ${ }^{120}$

The ADA's prohibition against discrimination provides, "No individual shall be discriminated against on the basis of disability in the full and equal enjoyment of the goods, services, facilities, privileges, advantages, or accommodations of any place of public accommodation by any person who owns, leases (or leases to), or operates a place of public accommodation." 121 There are two activities considered discriminatory according to the ADA that are relevant to this analysis. ${ }^{122}$ First, the ADA prohibits denial of participation, which prevents a disabled individual from being denied the opportunity to "participate in or benefit from the goods, services, facilities, privileges, advantages, or accommodations of an entity" based on the disability. ${ }^{123}$ Second, the ADA also prohibits participation in an unequal benefit, which bans a public accommodation from providing an opportunity to participate in its services if the services are not equally provided to the disabled and non-disabled alike. ${ }^{124}$ Public accommodations must also offer their services to individuals "in the most integrated setting appropriate to the needs of the individual." 125

Based on the previously stated definitions, it is clear that restaurants that do not offer menu items that are guaranteed gluten free are in violation of the ADA.

$119 I d$. (emphasis in original).

120 See Eat Smart, Food Allergies, OLIVEGARDEN.COM, http://www.olivegarden.com/nutrition\#food-allergies (last visited Mar. 22, 2015); Applebee's Allergen Information, APPLEBEES.COM, http://www.applebees.com/ /media/docs/Applebees_Allergen_Info.pdf (last visited Mar. 22, 2015).

12142 U.S.C. $\S 12182(\mathrm{a})(2015)$.

122 See id. $\S 12182(\mathrm{~b})(1)(\mathrm{A})$.

123 Id. $\S 12182(\mathrm{~b})(1)(\mathrm{A})(\mathrm{i})$.

124 Id. $\S 12182(\mathrm{~b})(1)(\mathrm{A})(\mathrm{ii})$.

125 Id. $\S 12182(\mathrm{~b})(1)(\mathrm{B})$. 
Individuals with celiac disease are discriminated against on the basis of their inability to consume even trace amounts of gluten, which is the root cause of their disability. By not providing gluten free options and eliminating the risk of cross-contamination, celiac disease sufferers are not provided with "the full and equal enjoyment of the goods, services, facilities, [and] privileges ..." that are offered by the restaurant. ${ }^{126}$ Therefore, restaurants (a public accommodation) are discriminating against celiac disease sufferers (disabled individuals) on the basis of their inability to consume gluten by not providing guaranteed gluten free products, which ultimately denies the individuals the opportunity to "participate in or benefit from the goods, services, facilities, privileges, advantages, or accommodations of an entity." 127

The question now becomes what must be done in order for a restaurant to become compliant with the ADA regarding this issue. A restaurant can avoid discrimination by "mak[ing] reasonable modifications in policies, practices, or procedures, when such modifications are necessary to afford such goods, services, facilities, privileges, advantages, or accommodations to individuals with disabilities, unless the entity can demonstrate that making such modifications would fundamentally alter the nature of such goods, services, facilities, privileges, advantages, or accommodations." 128

Guidance for determining what constitutes a reasonable modification comes from Beale v. Aardvark Day Care Center. ${ }^{129}$

First, modifications are not required where they would "fundamentally alter" the nature of the public accommodations['] goods and services. Second, modifications are not required if the entity can demonstrate that

126 Id. $\S 12182(\mathrm{a})$.

127 Id. $\S 12182(\mathrm{~b})(1)(\mathrm{A})(\mathrm{i})$.

128 Id. § 12182(b)(2)(A)(ii).

129 Beale v. Aardvark Day Care Ctr., No. 00-413, 2000 U.S. Dist. LEXIS 19300, at *14 (E.D. Pa. Dec. 29, 2000). 
taking such steps would result in an undue burden. Significant difficulty or expense in making an accommodation constitutes an undue burden. Third, modifications are not required if doing so would pose a direct threat to the health and safety of others. ${ }^{130}$

The DOJ report following the Lesley University settlement said restaurants are not required to provide gluten free options as a reasonable modification. ${ }^{131}$ The only reasonable modifications required would be for them to answer questions about the ingredients in a menu item if they are known and to substitute or omit ingredients upon request if the restaurant would do it for any patron. ${ }^{132}$ This seems like a far cry from the "full and equal enjoyment" mandate of the ADA, and offers substantially less "protection" to celiac disease sufferers than is offered to other individuals under the statute.

IV. Disproportionate Protection: Why the ADA As APPLIED BY THE DOJ CREATES A DOUBLE STANDARD BY Protecting Certain Disabilities MoRe Than OTHERS AND WHAT SHOULD BE DONE.

\section{A. A Truly Protected Disability}

Reasonable modifications for people using wheelchairs or other mobility devices because of qualified disabilities under the ADA provides a good example of why restaurants should be required to do more than what is set forth by the DOJ following the Lesley University settlement to accommodate individuals with celiac disease. All public accommodations considered "new construction," which are constructed for first occupancy after January 26, 1993, are required to be "readily accessible and usable by individuals with disabilities."133 Any alteration to the facilities of a public

130 Id. at *15 (internal citations omitted).

131 Questions and Answers, supra note 76.

132 Id.

13328 C.F.R. $\S 36.401(\mathrm{a})(1)(2015)$. 
accommodation made after January 26, 1992, are required to be readily accessible to and usable by individuals with disabilities "to the maximum extent feasible . . .."134 An alteration is defined as "a change to a place of public accommodation or a commercial facility that affects or could affect the usability of the building or facility or any part thereof." 135 Examples of alterations include, but are not limited to, remodeling, renovation, and rehabilitation. ${ }^{136}$ When discussing the definition of "to the maximum extent feasible," the Code of Federal Regulations implies that it will only be under rare circumstances that a facility will be excused from fully complying with the applicable standards:

The phrase "to the maximum extent feasible". . - applies to the occasional case where the nature of an existing facility makes it virtually impossible to comply fully with applicable accessibility standards through a planned alteration. In these circumstances, the alteration shall provide the maximum physical accessibility feasible. Any altered features of the facility that can be made accessible shall be made accessible. ${ }^{137}$

When making alterations to a facility, the alterations must be fully accessible to disabled individuals so long as the cost of the alterations needed to provide handicapped accessibility does not exceed $20 \%$ of the total cost of the project. 138 If the $20 \%$ limit would be exceeded in providing full accessibility to the altered project, the $20 \%$ should first be allocated to providing an accessible entrance, an accessible route, and then to accessible restrooms. ${ }^{139}$

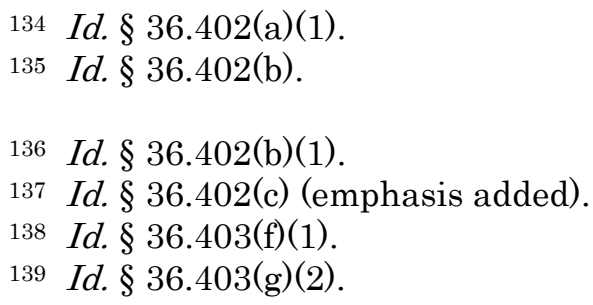


The DOJ created the 2010 ADA Standards for Accessible Design that sets out "scoping and technical requirements for accessibility to sites, facilities, buildings, and elements by individuals with disabilities." 140 These are the specific requirements that have to be met during new construction or alteration of a facility in order to be in compliance with the ADA. ${ }^{141}$ There are specifications touching on everything from amusement park rides to judicial facilities. For purposes of this analysis only specifications pertaining to restaurants will be discussed. First of all, at least one accessible route must be provided from accessible parking spaces and accessible streets and sidewalks, ${ }^{142}$ and the accessible ramp cannot have a slope steeper than $1: 12 .{ }^{143}$ If the total number of parking spaces provided by a place of public accommodation is between one and twenty-five, there must be at least one accessible space, and the number increases as the total number of parking spaces increases. ${ }^{144}$ If bathroom facilities are provided, they have to meet specific accessibility requirements including amount of floor space and door width. ${ }^{145}$ Where surfaces are provided for dining, at least 5\% of the seating spaces must meet accessibility criteria. ${ }^{146}$ At least one food service counter has to be accessible in terms of maximum height requirements to accommodate those seated in wheelchairs. ${ }^{147}$ All walking surfaces that are part of an accessible route must not have a slope steeper than 1:20 and have to be at least thirty-six inches wide. ${ }^{148}$ These are a few, but not all, of the requirements that must be met by a restaurant or other place of public accommodation any time

1402010 ADA Standards for Accessible Design, DeP’T of Just. (Sept. 15, 2010) http://www.ada.gov/regs2010/2010ADAStandards/ 2010ADAstandards.htm\#titleIII [hereinafter ADA Standards for Accessible Design].
141 Id.
142 Id.
143 Id.
144 Id.
145 Id.
146 Id.
147 Id.
148 Id. 
there is new construction, and they have to be done up to $20 \%$ of the total cost of any alteration an existing restaurant undertakes. 149

As for existing places of public accommodation that have not undergone new construction or alteration, Title III of the ADA requires them to remove architectural barriers to access when the removal is "readily achievable." ${ }^{150}$ Readily achievable is defined by the ADA as "easily accomplishable and able to be carried out without much difficulty or expense." 151 Whether or not something is considered readily achievable is typically based on cost and other factors of financial means of the facility. ${ }^{152}$ Legislative history shows that, regardless of cost, Congress believed installing ramps, grab bars in restrooms, and rearranging tables was nearly always readily achievable. 153

As evidenced by the 2010 ADA Standards for Accessible Design, the DOJ has gone to great lengths to ensure that disabled individuals using mobility devices are able to access the goods and services available by public accommodations such as restaurants. It is not a question of whether or not an accessible feature is reasonable for the facility, but rather how many of them are reasonable and what specifications must be used to make them accessible. The only time a modification is not considered reasonable is if it exceeds $20 \%$ of the total cost of the alteration. ${ }^{154}$

Even if the restaurant is not going through new construction or another type of alteration, it is still required to remove any architectural barriers to access that are readily achievable which, at minimum requires an accessible ramp, grab bars in restrooms, and rearranged seating. 155 It would be extremely difficult for a restaurant to not be accessible to individuals in wheelchairs and still be in compliance with the ADA.

149 See 28 C.F.R. § 36.401 (2015); § 36.402; § 36.403.

150 Pinnock v. Int'l House of Pancakes Franchisee, 844 F. Supp. 574, 581 (S.D. Cal. 1993).

151 Id.

152 Id.

153 Id.

15428 C.F.R. § 36.403(f)(1) (2015).

155 Pinnock, 844 F. Supp. at 581. 


\section{B. Lack of Protection for Celiac Sufferers}

Nowhere in the ADA is a distinction made between disabilities for the purpose of protecting one class of disabled individuals more than another. The failure to remove architectural barriers is listed as a type of prohibited discrimination by a place of public accommodation just the same as the failure to make reasonable accommodations. 156 However, according to the DOJ, the only thing restaurants have to do to avoid discriminating against individuals with celiac disease is to answer questions about ingredients in menu items and omit or substitute ingredients from certain items if the restaurant allows all patrons to do so. ${ }^{157}$ This would be the equivalent of saying that a restaurant is only required to have a wheelchair ramp if it was company policy to do so.

The DOJ justified the enormous difference between the modifications it mandated to Lesley University in order to be in compliance with the ADA and the simple guidelines for restaurants on the basis that it is not mandatory to eat at restaurants. ${ }^{158}$ Using this logic, restaurants would not be required to conform to the ADA at all. It is not likely that it would ever be mandatory for a person using a mobility device to eat at a restaurant, yet the DOJ mandates rigorous compliance standards that restaurants must abide by in order to accommodate disabled individuals with wheelchairs. In the same way that the ADA does not distinguish between the kinds of disabilities by level of importance, it also does not distinguish between mandatory and optional services offered by public accommodations. 159 Essentially, there is no basis anywhere in the ADA for setting the threshold for what is considered a reasonable modification higher than the threshold for any other form of discrimination, such as barriers to access; however, a person in a wheelchair or using another mobility device is much more likely to be provided the goods and services of a

\footnotetext{
15642 U.S.C. § $12182(\mathrm{~b})(2)(\mathrm{A})(\mathrm{iv})(2015)$.

157 Questions and Answers, supra note 76.

158 Id.

159 See 42 U.S.C. $§ 12182$ (2015).
} 
restaurant than an individual that suffers from celiac disease.

\section{What Should Be Done}

Because of the ADA Amendments Act of 2008's expansion of the definition of disability, restaurants that do not offer gluten free options discriminate against sufferers of celiac disease by denying them the ability to participate in the goods and services offered by the restaurant based on the individuals inability to consume gluten. 160 This relatively new form of discrimination has been allowed due to the fact that all a restaurant has to do to continue discriminating while remaining compliant with the $\mathrm{ADA}$ is to comply with the extremely low reasonable modifications standard set forth by the DOJ following the Lesley University settlement. ${ }^{161}$ In order to combat this continued discrimination the reasonable modification standard for adjusting procedures to provide goods and services to celiac disease sufferers needs to be applied more like the "readily achievable" standard for providing access to restaurants for disabled individuals using wheelchairs and other mobility devices to provide minimum gluten free accommodations at all restaurants.

The risks of cross-contamination could be greatly reduced by doing as little as having a dedicated set of gluten free utensils and cookware. ${ }^{162}$ This may seem like an unreasonable expense, but the average cost of a wheelchair ramp that Congress considers to be readily achievable varies from \$80-120 per linear foot. ${ }^{163}$ As mentioned previously, the slope of the ramp cannot be more than 1:12, meaning that for every one foot the ramp needs to go up, it must be at least twelve feet long. Therefore, a wheelchair ramp that spans a vertical incline of one foot and is twelve

160 See id.

161 Questions and Answers, supra note 76.

162 See Derr, supra note 14.

163 Samir Shah On Mon, Practical Tips for Adding a Wheelchair Ramp to Your Home, MDA/ALS NEWSMAGAZINE (June 3, 2013, 2:15 PM), http://alsn.mda.org/article/practical-tips-adding-wheelchair-rampyour-home. 
feet long would cost between $\$ 960$ and $\$ 1,440$ according to the cost estimates. This would make a wheelchair ramp far surpass the cost of a set of cookware to dedicate for gluten free food preparation. Also, much like rearranging seating to ensure at least 5\% of the restaurant is accessible, which is considered readily achievable by the legislature prior to any new construction or alterations, 164 so too should ensuring that $5 \%$ of the menu can be made available to accommodate individuals with celiac disease. Taking these measures alone would greatly increase the safety of and access to restaurant dining for celiac disease sufferers.

Furthermore, the same construction standards that are used to mandate accessibility for restaurants should apply to gluten free accommodations. Whenever a new restaurant is being constructed, there should be guidelines developed for gluten free preparation areas in kitchens that are set forth in the same way as the accessibility guidelines were laid out in the 2010 ADA Standards for Accessible Design. 165 Also, like the Standards for Accessible Design, any time an existing restaurant undertakes a kitchen alteration the plans should be required to provide for gluten free accommodations to the extent of $20 \%$ of the total cost of the alteration.

There should also be no distinction between the accommodations considered reasonable for "mandatory" services provided by places like Lesley University and "voluntary" services provided by restaurants. The ADA does not differentiate between mandatory and voluntary for the purposes of applying the reasonable modifications standard, it only differentiates between the type of entity providing the service. ${ }^{166}$ All of the relevant mandates of the Lesley University Settlement Agreement should be used as guidelines for the reasonable modification standards of restaurants. ${ }^{167}$ This would be a good starting point for implementing standards for restaurants to follow until

164 ADA Standards for Accessible Design, supra note 140.

$165 \mathrm{Id}$.

166 See 42 U.S.C. $§ 12182$ (2015)

167 Settlement, supra note 1. 
further amendments could be made to tailor the requirements more specifically to the restaurant industry.

Setting a standard for the types of menu items that would be required to prevent a restaurant from discriminating against individuals with celiac disease could prove quite difficult at the beginning. It would admittedly be challenging if there were specific items of food that restaurants were mandated to provide as gluten free options. However, the DOJ provided a good starting point in the Agreement by stating that the gluten free options in the meal plan must be nutritionally comparable to the food offered on the "normal" menu. Although this is not a particularly descriptive standard, it gives enough guidance to infer that the gluten free options offered on a restaurant's menu would have to be similar to the restaurant's other menu items. For example, an Italian restaurant would not be able to offer a garden salad as its only gluten free option. Instead, the restaurant would likely be required to develop gluten free pasta dishes that are comparable to those offered on the "normal" menu.

Regardless of when gluten free options are added to the menu the option should have to be certified gluten free. Much like a wheelchair ramp that is too steep, a gluten free menu item that is not certified as gluten free, which most current restaurants do not offer, would be ultimately useless because it would not allow individuals with celiac disease to dine at the restaurant. The ingredients used in meals should have to comply with the new Federal Drug Administration ("FDA") labeling standards for gluten free foods of twenty parts per million ("ppm") just like the accessibility modifications have to apply to specific standards. 168

In order to ensure that the gluten free food is not then made unsafe through cross-contamination, the restaurant's kitchen should have to be certified by an organization like the National Foundation for Celiac Awareness ("NFCA") or the Gluten Intolerance Group ("GIG"). GIG offers a program called Gluten Free Food Service \& Management

16821 C.F.R. $§ 101.91$ (2015). 
Training ("GFFS") that independently verifies food preparation policies and procedures of restaurants. 169 NFCA also offers a training program for food service professionals regarding safe food handling and preparation in order to prevent cross-contamination. ${ }^{170}$ Having educated employees implementing food preparation procedures created specifically to make food safe for sufferers of celiac disease would provide more gluten free options without a restaurant even changing its menu. For example, the restaurants such as Applebee's that already have gluten free menus but are unable to verify that crosscontamination has not occurred would be able to remove that disclaimer and easily have a menu that would not discriminate against individuals with celiac disease.

Just when all of this seems like an overly burdensome and nearly impossible feat, an example of a restaurant that has successfully implemented these procedures emerges. California Pizza Kitchen, Inc. ("CPK") is a pizza chain with more than 200 restaurants. ${ }^{171}$ In 2010, the company started making a gluten free pizza crust available at its restaurants, but like many of the restaurants previously discussed, did not ensure the gluten free option was completely gluten free. ${ }^{172}$ Customers immediately began to complain, and the chain pulled the gluten free crust off of its menu. ${ }^{173}$ CPK then began work with GIG to restructure its kitchen operations and train its employees on how to avoid cross-contamination. ${ }^{174}$

The new procedures that CPK has implemented are very thorough. Gluten free pizza crusts arrive at the restaurant

169 Get Certified, GLUTEN InTOLERANCE Group, http://www.gffoodservice.org/get-gffs-certified/process/ (last visited Aug. $12,2015)$.

170 Gluten-Free Certification, NAT'L Found. FOR CELIAC AwAREness, http://www.celiaccentral.org/gluten-free-certification/ (last updated Mar. $23,2015)$.

171 Julie Jargon, At Restaurants, Gluten-Free is a Tough Recipe, WALL ST. J. (Dec. 15, 2013, 7:37 PM), http://online.wsj.com/ news/articles/SB10001424052702304579404579234201223974792.

172 Id.

173 Id.

174 Id. 
locations in sealed bags and are pre-stretched. ${ }^{175}$ There are areas designated solely for the preparation of gluten free pizzas. ${ }^{176} \mathrm{CPK}$ separates the ingredients for gluten free and regular pizzas using color-coded bins. ${ }^{177}$ A manager also supervises the preparation of every gluten free pizza. ${ }^{178}$ Rice flour, which is gluten free, is used to stretch all normal pizza dough in order to further prevent cross-contamination due to flour particles in the air coming in contact with the gluten free ingredients. ${ }^{179}$ Finally, the pizzas are placed in the oven on disposable aluminum trays so that they do not come into contact with the regular pizza crusts or the surface that the regular pizza crusts are cooked on. 180

Although this may seem rather intense, CPK said the changes did not cost much. ${ }^{181}$ The most significant investment the company found was the time to train employees. ${ }^{182} \mathrm{CPK}$ also charges $\$ 2$ extra for gluten free pizza crust to help cover the costs of providing the item. 183 The company recognizes that the changes were well worth it because of the rapidly growing demand for gluten free food even though sales of gluten free pizzas currently make up less than $5 \%$ of CPK's sales. ${ }^{184}$

Following the lead of CPK, Pizza Hut has recently announced and implemented a certified gluten free pizza at thousands of its stores across the nation. ${ }^{185}$ The GIG certified preparation procedures implemented by Pizza Hut are very similar to those used by CPK. ${ }^{186}$ The ingredients and utensils are stored in specific gluten free containers, the employee preparing wears gloves, the pizza is put into the

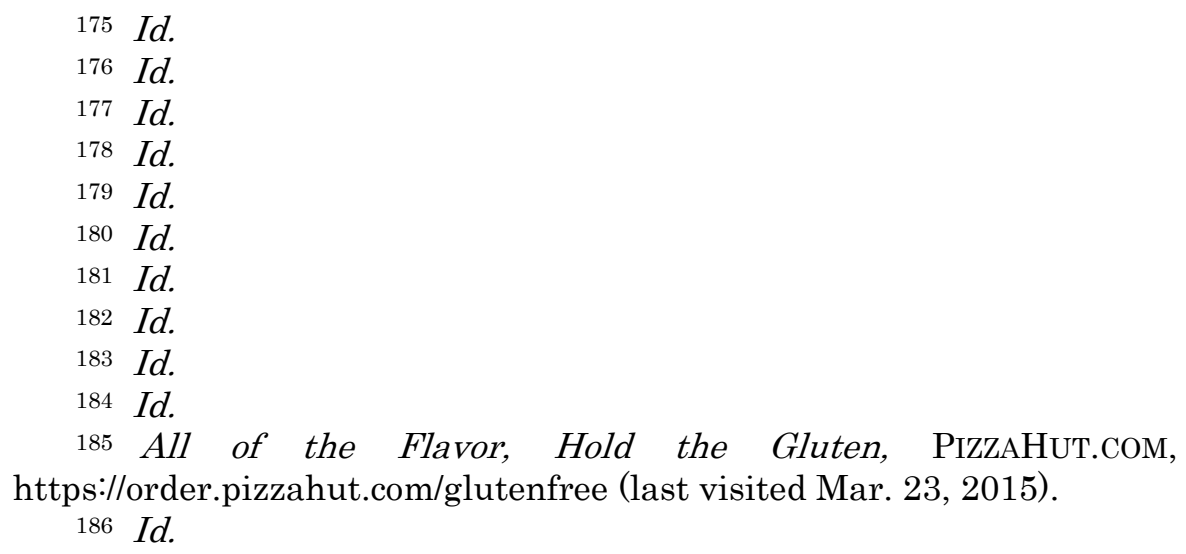


oven on protective parchment paper, and it is even cut with a designated gluten free pizza cutter. ${ }^{187}$ This is just another example of the feasibility of a national chain becoming gluten free.

These companies have provided a model that all other restaurants could follow in order to implement truly gluten free options onto their menus. They have also shown that the modifications necessary to do so are not as costly or burdensome as one may originally think.

\section{Lessons from Abroad}

The United States is not the only country that has seen an increase in the diagnosis of celiac disease in recent years. It is projected that about $1 \%$ of the populations of western countries have celiac disease. ${ }^{188}$ There are varying levels of accommodation for celiac sufferers among these countries. 189 For example, the United Kingdom provides individuals diagnosed with celiac disease prescriptions that permit them to buy gluten free food at little or no cost to them because the individuals are reimbursed through their health insurance. ${ }^{190}$ Canada allows for tax deductions of the "incremental cost associated with the purchase of gluten free products, as compared to the costs of comparable nongluten free products." 191 These are all significant policies that undoubtedly ease the burden on celiac sufferers, but one country goes above and beyond in offering extreme protections to those diagnosed with celiac disease.

The accommodations offered by Italy to individuals with celiac disease are the most significant in the world as well as the most relevant in comparison to the protections that should be offered by the ADA. Italian celiac sufferers are

187 Id.

188 International Variations in Government Policy Concerning Celiac Disease, GLUTINO (Aug. 30, 2010), http://www.glutino.com/ourstory/news/variations-in-international-government-policy-concerningceliac-disease/.

189 Id.

190 Id.

191 Id. 
given a stipend of nearly $\$ 200$ dollars per month to purchase gluten free foods and ease the financial burden that increased prices of gluten free goods can cause. ${ }^{192}$ Not only are they given extra money, but they are also given extra vacation time to account for the added time it can take to shop for and prepare gluten free foods. ${ }^{193}$ The most remarkable accommodation offered by the Italian government is that the law in Italy mandates that gluten free food be available in schools, hospitals, and public places such as restaurants. ${ }^{194}$ If a country known for its bread and pasta, both traditionally products containing gluten, has been able to offer such effective and progressive accommodations to its celiac population, then the United States should be able to learn from Italy's example and implement similar policies and protections to offer relief to the roughly two million people in the country that struggle with the disease every day.

\section{E. Solutions for the Cost of Compliance}

It is evident that the cost of making alterations to a restaurant kitchen in order for it to be able to produce certified gluten free options could be significant. From a separate set of pots, pans, and utensils to a designated food preparation area, mandating that all restaurants provide gluten free options could prove crippling from a financial standpoint for smaller "mom and pop" restaurants. One way to alleviate this burden would be to amend the Internal Revenue Code ("IRC") to provide tax deductions for the alterations necessary to provide certified gluten free options. Section 190 of the IRC currently allows any "qualified architectural and transportation barrier removal expenses" up to $\$ 15,000$ to be classified and written off as an ordinary business expense for tax purposes. 195

192 Id.

193 Id.

194 Celiac Policies Around the World, CELIAC Disease Found., http://celiac.org/celiac-disease/resources/celiac-policies-around-theworld/ (last visited Mar. 23, 2015).

195 I.R.C. $\S 190$ (2015). 
Essentially, this allows a restaurant to deduct any of the expenses it incurs in becoming compliant with the ADA's accessibility standards. If $\S 190$ of the IRC were to be amended to include any expenses incurred in becoming compliant with Title III of the ADA, restaurants would also be able to deduct the expenses incurred in purchasing the new equipment and training necessary to provide certified gluten free options. The $\$ 15,000$ limitation should also be amended to allow for up to that amount to be deducted for the necessary alterations per restaurant location. It is unlikely that any single restaurant location would have to incur expenses even close to that amount, but it would ensure that all expenses relating to ADA compliance efforts by restaurant chains would be covered. Therefore, making a slight amendment to the IRC would significantly reduce, if not alleviate altogether, the financial burden put on the "mom and pop" restaurants by requiring them to offer certified gluten free menu options in accordance with the $\mathrm{ADA}$, and potentially reduce much of the prospective resistance to these mandates.

\section{F. Crime and Punishment}

In order to encourage restaurants to comply with the new standards, it would likely be necessary for the DOJ to fine restaurants that do not comply. Under Title III of the ADA the DOJ can sue to enforce compliance and obtain civil penalties up to $\$ 55,000$ for the first violation and as much as $\$ 110,000$ for any violation after that. ${ }^{196}$ However, the DOJ has to go through settlement talks before it can sue a party. ${ }^{197}$ Making it known that Lesley University had to pay one individual $\$ 50,000$ to dismiss a claim as a result of its settlement with the DOJ would most likely be enough to get most restaurants to comply before complaints against

196 United States Department of Justice Civil Rights Division, Department of Justice ADA Responsibilities: ADA Enforcement, ADA.GOV, http://www.ada.gov/enforce_footer.htm (last visited Mar. 23, 2015).

197 Id. 
them were even filed. The most effective method of enforcement for those that fail to comply with the new standards would be to fine the restaurants on a case-by-case basis to the extent that it does not do irreparable financial damage to the restaurant, but to the point that avoiding the fines becomes a financial incentive to become compliant.

\section{CONCLUSION}

The definition of disability has been vastly expanded by the ADA Amendments Act of 2008. Individuals that suffer from celiac disease are now considered disabled under the expanded definition. Furthermore, restaurants have to adhere to Title III of the ADA because they are considered places of public accommodation. However, restaurants discriminate against individuals with celiac disease by not offering certified gluten free menu options because it denies the individuals the ability to participate in the goods and services offered by the restaurant on the basis of their inability to consume gluten. The settlement between the DOJ and Lesley University regarding its meal plan's lack of accommodations for those students with celiac disease exposed this disparity as well as the liability that could result from an application of the ADA to food service providers that fail to provide gluten free food.

It has been evidenced in this Note that the compliance standards that restaurants are held to in regards to being accessible to the disabled using mobility devices are vastly higher than the compliance standards for restaurants regarding serving individuals with celiac disease. Because of this, the actions taken by restaurants in order to avoid officially discriminating against people with celiac disease should be made comparable to the actions that must be taken to be compliant in terms of accessibility. It has been proven by acts of other countries such as Italy and restaurants such as California Pizza Kitchen that it is possible to successfully implement procedures that adequately protect celiac sufferers. The time has come for the government to recognize the rights of individuals with 
celiac disease under the $\mathrm{ADA}$ and to put an end to this expansive discrimination. 